\title{
The Economic Influence on the Healthcare System in Romania
}

\author{
Ludmila Daniela MANEA $^{\star}$, Florina Oana VIRLANUTA ${ }^{\star \star}$
}

\begin{tabular}{l}
\hline \multicolumn{1}{c}{ A R T I C L E I N F O } \\
\hline Article history: \\
Accepted December 2019 \\
Available online December 2019 \\
\hline JEL Classification \\
I18, I15, H19, H20 \\
Keywords: \\
Public economics, Healthcare \\
system, Romania
\end{tabular}

\begin{abstract}
A B S T R A C T
Health, in a wider sense cannot be separated from economic development and quality of life. The relations between health, economy and progress are complex and coexist in a total interdependence, health being both a sine qua non condition and an effect of economic development.In this article we conducted research on identifying factors leading to increasing current expenditure on health per capita. Evidence proportion of older people in the population structure has been shown to help explain current health spending per capita.
\end{abstract}

(C) 2019 EAI. All rights reserved.

\section{Introduction}

Health, in the broad sense, cannot be separated from economic development and quality of life. Relationships between health, economics and development are complex and there is a complete interdependence, while health can be a sine qua non condition or effect for economic development [8]. The main effects of economic development were industrialization by improving the life conditions (diet, housing etc.). Subsequently, urbanization has changed and raise the level of education and information (specialization of teaching, medical and paramedical professions), induced changes in the way of life and behavior (healthy lifestyle) [9]. These mutations are felt in the development and (re) organization of health care through diversification and specialization, adopting the most efficient social insurance system. [2]

System Health Insurance (SHI) in Romania remained very centralized, despite recent efforts decentralization of regulatory functions. At national level, the Ministry of Health provides overall management, political and regulatory oversight, while local, regional public health authorities are responsible for service delivery. Similarly, the National Health Insurance manages and regulates the health insurance system through territorial houses contracting health services [1].

Health expenditure expressed in economic and overall outcome of the interaction, activity of the various players in the healthcare system: consumers, producers and bodies involved in health programs or finance them (paying agent) [9].

At 814 euros per capita (value adjusted for differences in purchasing power), Romania spends less than one third of the EU average, the lowest of all Member States. The share of GDP devoted to health (4.9\%) is the lowest and significantly below the EU average of 9.9\%. [12] Health expenditure as a share of GDP have declined steadily since 2000, reflecting the unstable political situation and as a result of spending cuts to achieve budget deficit targets. However, public sources account for $78 \%$ of total health funding (on a par with the EU average). "Payments of pocket" is the second source of revenue for health care, and in 2017 came the first time to $21 \%$ of charges. Although detailed data are not available, results of studies indicate that informal payments, particularly for hospital care are widespread and substantial[11].

\section{Data analysis}

Public spending has affected the health sector in Romania, quality access to services, especially the poorest and most vulnerable segments of the population, which includes many elderlies. There are no data on health spending by age, but certainly they increase to the older age categories, because the medical care for the elderly technologically are more expensive, the hospitalization are prolonged, care and supervision are more costly [10].

In Romania proportion of older people in the population structure has increased from $13.2 \%$ in 2000 to $17.8 \%$ in 2017 . In this context, attempting to observe the influence of older persons on current expenditure on health per capita. It included data on the period 2000-2017 and current expenditure on health per capita

\footnotetext{
`, ${ }^{\star \star}$ Dunarea de Jos University of Galati, Romania. E-mail addresses: daniela.manea@ugal.ro (L. D. Manea - Corresponding author), florinaoana27@yahoo.com (F. 0.Virlanuta)
} 
and the share of elderly in the total population.

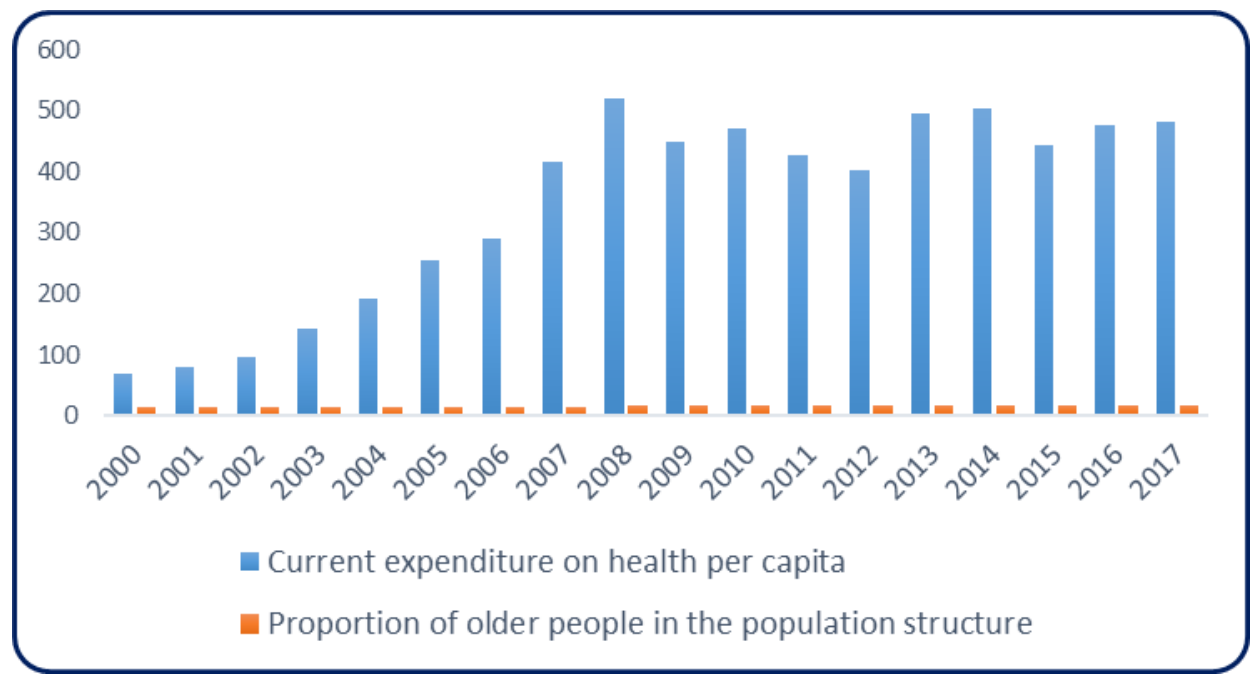

Figure 1. The evolution of current expenditure on health care and proportion of older people in the population structure in Romania 2000-2017 (data taken from Eurostat)

According to the annual review under the new European methodology SHA 2011 current expenditure on health per capita registered a continuous increase during 2000-2017 from 69.89 euro per capita in 2000 to 480.88 euro per capita in $2017[14]$.

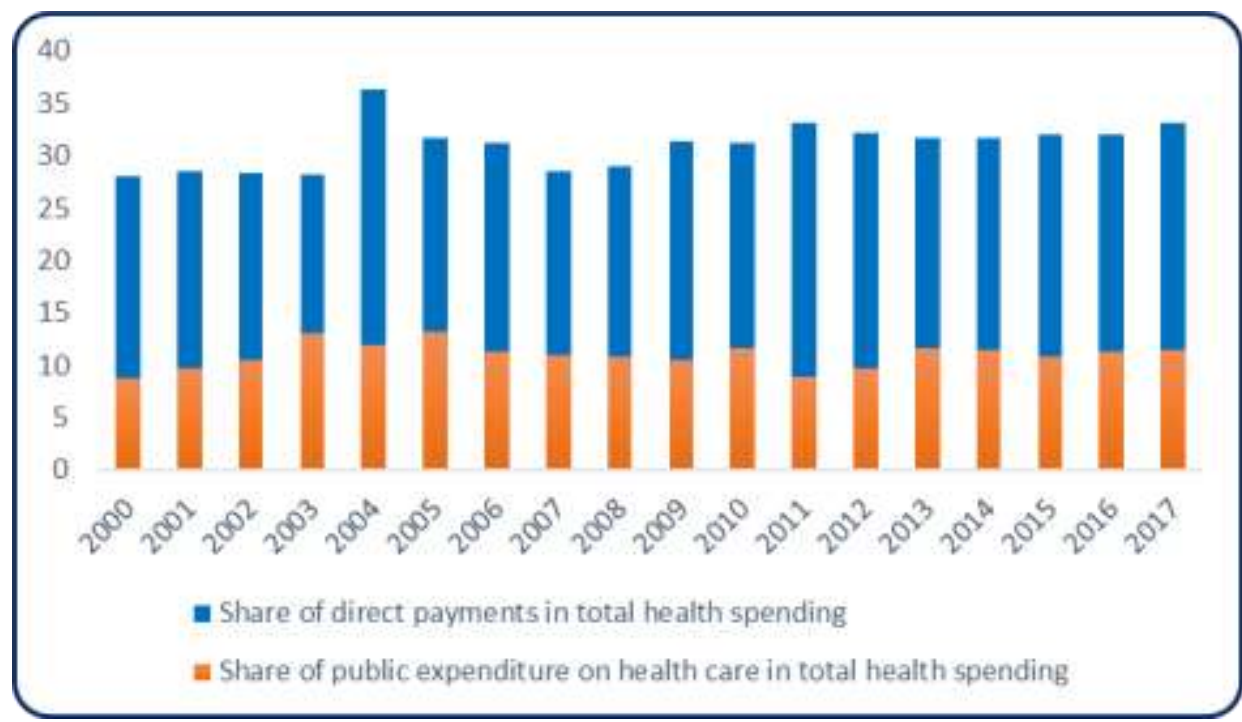

Figure 2. The evolution of share of public expenditure on health care in total health spending and share of direct payments in total health spending in Romania 2000-2017 (data taken from Eurostat)

The most important source of funding for current health expenses represent public funds, which increased in 2017 by 8.9\% compared to 2016 (from 27490.390 million in 2016 to 29.937809 million in 2017). Compared with 2000, current expenditures of publicly funded health increased in 2017 by $51.4 \%$ (with 10.157948 million). The largest share of public spending was financed from social security funds (FNUASS and BASS), their share in total current expenditure increased slightly from $64.5 \%$ in 2016 to $65.2 \%$ in 2017. The second category of funding sources to cover current health represents private sources or direct payments by households. These expenses increased in 2017 by $5.8 \%$ compared to 2016, from 7.495625 million in 2016 to 7.930297 million in 2017[13].

\section{Research methodology}

Methods and statistical techniques to quantify, factor analysis, estimation and testing are the many extended range of statistical and mathematical methods and tools. The most significant of these methods and tools are applied in one form or another on the input data available in order explicitness factors and, consequently, to obtain the information necessary to support decision action. 


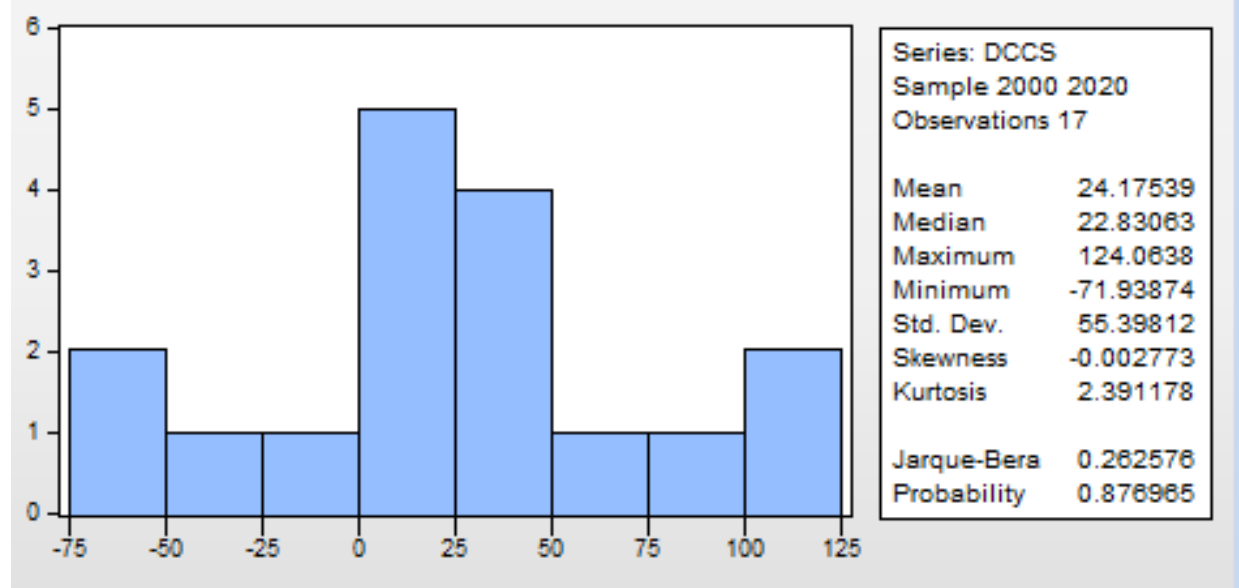

Figure 3. Statistical test performed for current expenditure on health per capita

After checking the stationarity and ADF and PP test series becomes stationary of order 1, so the flatness Kurtosis coefficient analysis, we can say that the series of current expenditure on health per capitahas an asymmetric distribution about normal and smooth. Descriptive statistics of the variables analyzed were made using econometric software "Eviews 8".

To achieve forecast current expenditure on health per capita, in Romania, we considered the explanatory indicator proportion of older people in the population structure. Using time series analysis, attempts to verify the hypothesis of whether a dependency between the proportion of older people and current expenditure on health per capita in Romania.

The correlation between health and current expenditure per capita and exogenous variable proportion of older people in the total population, can be checked by using a logarithmic model.

$$
\log (y t)=a+(b) \log (x t)+\varepsilon_{t}
$$

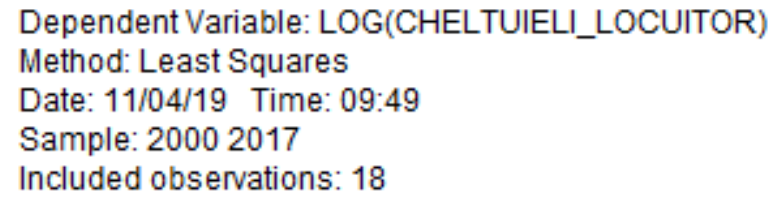

\begin{tabular}{lrlll}
\hline \hline \multicolumn{1}{c}{ Variable } & Coefficient & Std. Error & t-Statistic & Prob. \\
\hline \hline LOG(PONDEREA_PV) & 6.553282 & 0.961707 & 6.814221 & 0.0000 \\
\multicolumn{1}{c}{ C } & -12.22280 & 2.627310 & -4.652211 & 0.0003 \\
\hline \hline R-squared & 0.743728 & Mean dependent var & 5.670982 \\
Adjusted R-squared & 0.727711 & S.D. dependent var & 0.687978 \\
S.E. of regression & 0.358996 & Akaike info criterion & 0.893430 \\
Sum squared resid & 2.062053 & Schwarz criterion & 0.992360 \\
Log likelihood & -6.040869 & Hannan-Quinn criter. & 0.907071 \\
F-statistic & 46.43360 & Durbin-Watson stat & 0.356073 \\
Prob(F-statistic) & 0.000004 & & \\
\hline \hline
\end{tabular}

$$
\text { LOG(CCS) }=6.55328206554 * \text { LOG(PONDEREA_PV) }-12.2228034853
$$

Interpretation of regression shows that the increasing ratio of elderly persons / total population $1 \%$ of current health spending per capita will increase by $6.55 \%$. Thus, it was confirmed influence elderly share in total public spending on health care changes.

Homoscedasticitate test model show that the intensity of the influence of exogenous variable (proportion of older people in the population structure) on endogenous variable (current expenditure on health per capita) do not differ significantly over time, so the model is homoscedastic. To test the validity (significance) model parameters, rejecting the null hypothesis and accept the contrary. So, the parameter $\mathrm{b}$ is significantly different from zero at the population level, which means that proportion of older people in the population structure is a significant factor for current expenditure on health per capita.

It obtained a correlation coefficient of 0.743 , which confirms the strong relationship between the 
endogenous and exogenous variables. Obviously, the R2 take values close to 1, the regression model adjusted better data sample.

Because public spending for healthcare and direct payments had the largest share (90\%) of the total current expenditure on health care in Romania, attempts to correlate current expenditure on health per capita public expenditure on health care and direct payments in order to determine whether indeed their growth influences the growth of total expenditure on health care. In this context we used data for the period 2000-2017 the share of public expenditure on health care in total health spending and the share of direct payments in total health expenditures.

The correlation between health spending and exogenous variables can be checked by using multifactorial linear model. Thus, multiple linear econometric model considered the following form:

$$
\mathrm{y}_{\mathrm{t}}=\mathrm{a}_{0}+\mathrm{a}_{1} * \mathrm{X} 1_{\mathrm{t}}+\mathrm{a}_{2} * \mathrm{X} 2_{\mathrm{t}}+\varepsilon_{\mathrm{t}}
$$

unde: $y_{t}$ - current expenditure on health per capita;

$\mathrm{x} 1_{\mathrm{t}}$ - ponderea cheltuielilor publice în totalul cheltuielilor pentru ocrotirea sănătăţii;

$\mathrm{x} 2 \mathrm{t}^{-}$share of public spending in total health spending;

$\mathrm{a}_{0}, \mathrm{a}_{1}, \mathrm{a}_{2}$ - model parameters;

$\varepsilon-$ Observation error.

When testing the link between yt and $\mathrm{X} 1, \mathrm{x} 2 \mathrm{t}$ rejecting the null hypothesis and accept the contrary; So, it was established that there is link between yt and $\mathrm{xt}$ at the population level.

\begin{tabular}{cccc}
\hline \hline Variable & Coefficient & Std. Error & \multirow{2}{*}{ t-Statistic } \\
\hline \hline LOG(PONDERE_CHELT_PUB) & 2.595774 & 1.430558 & 1.814519 \\
LOG(PONDERE_PLATI_DIRECTE) & 2.959189 & 1.381473 & 2.142053 \\
C & -9.382947 & 6.207960 & -1.511438 \\
\hline \hline
\end{tabular}

Estimators determine model parameters was done by least squares (LSM) for the period 2000 to 2017 and obtained the following regression:

$\log (\mathrm{CCS})=2.59577360951 * \log ($ pondere_chelt_pub $)+2.95918890708 * \log ($ pondere_plati_directe $)-$

$$
9.38294689603
$$

Interpretation of regression is as follows:

I. With the share of public expenditure on health care in total health spending $1 \%$ of current health spending per capita will increase by $2.60 \%$;

II. with an increased share of direct payments in total health spending $1 \%$ of current health spending per capita will increase by an average of 2.96 .

\section{The prognosis model}

Next will determine the type of model to model as well the dynamic behavior of current expenditure on health per capita. ARIMA model will be of the form $(p, 1, q)$, to identify the order $p$ and $q$ using the correlogram. To display correlogram will first create non-stationary series, that will make the differences of

\begin{tabular}{|c|c|c|c|c|c|c|c|c|}
\hline \multicolumn{2}{|c|}{ Autocorrelation } & \multicolumn{2}{|c|}{ Partial Correlation } & \multicolumn{2}{|r|}{$\mathrm{AC}$} & \multirow{2}{*}{$\begin{array}{l}\text { PAC } \\
0.059\end{array}$} & \multirow{2}{*}{$\begin{array}{c}\text { Q-Stat } \\
0.0692\end{array}$} & \multirow{2}{*}{$\begin{array}{c}\text { Prob } \\
0.792\end{array}$} \\
\hline 1 & 1 & 1 & 1 & 1 & 0.059 & & & \\
\hline 단 & 1 & - & 1 & 2 & -0.117 & -0.121 & 0.3644 & 0.833 \\
\hline & 1 & & 1 & 3 & 0.186 & 0.204 & 1.1601 & 0.763 \\
\hline $1 \square$ & 1 & $1 \square$ & 1 & 4 & -0.283 & -0.348 & 3.1459 & 0.534 \\
\hline 1 & 1 & 口 & 1 & 5 & 0.013 & 0.170 & 3.1506 & 0.677 \\
\hline 1 & 1 & 1 & 1 & 6 & 0.154 & -0.019 & 3.8425 & 0.698 \\
\hline $1 \square$ & 1 & 드 & 1 & 7 & -0.262 & -0.156 & 6.0664 & 0.532 \\
\hline 10 & 1 & 드 & 1 & 8 & -0.092 & -0.148 & 6.3703 & 0.606 \\
\hline 1 & 1 & 1 & 1 & 9 & -0.028 & -0.062 & 6.4015 & 0.699 \\
\hline 1 & 1 & $p$ & 1 & 10 & -0.053 & 0.082 & 6.5336 & 0.769 \\
\hline 1 & 1 & $1 \square$ & 1 & 11 & -0.038 & -0.219 & 6.6128 & 0.830 \\
\hline d & 1 & 10 & 1 & 12 & -0.070 & -0.060 & 6.9319 & 0.862 \\
\hline
\end{tabular}
the first order.

Figure 4. The correlogram of CCS series with OLS method 
The result is $\operatorname{ARIMA}(2,1,2)$

Equation applied (ec_arima_d_ccs):

$$
\text { d_ccs } c \text { AR(1) AR(2) AR(3) MA(1) MA(2) }
$$

\section{The stochastic forecasting}

Estimation Command:

=ニニニニニニニニニニニニニニニニニニニニニニニ=

LS LOG(CCS) C AR(1) AR(2) MA(1) MA(2)

Estimation Equation:

=ニニニニニニニニニニニニニニニニニニニニニニニ=

$\mathrm{LOG}(\mathrm{CCS})=\mathrm{C}(1)+[\mathrm{AR}(1)=\mathrm{C}(2), \mathrm{AR}(2)=\mathrm{C}(3), \mathrm{MA}(1)=\mathrm{C}(4), \mathrm{MA}(2)=\mathrm{C}(5), \mathrm{BACKCAST}=2002, \mathrm{ESTSMPL}=" 2002$ 2017"]

Substituted Coefficients:

=ニニニニニニニニニニニニニニニニニニニニニ=ニ

$\mathrm{LOG}(\mathrm{CCS})=6.19954509785+[\mathrm{AR}(1)=1.01756748221, \mathrm{AR}(2)=-0.223158165522, \mathrm{MA}(1)=-$ $0.0752053379959, \mathrm{MA}(2)=-0.924566994712, \mathrm{BACKCAST}=2002, \mathrm{ESTSMPL}=" 2002$ 2017"]

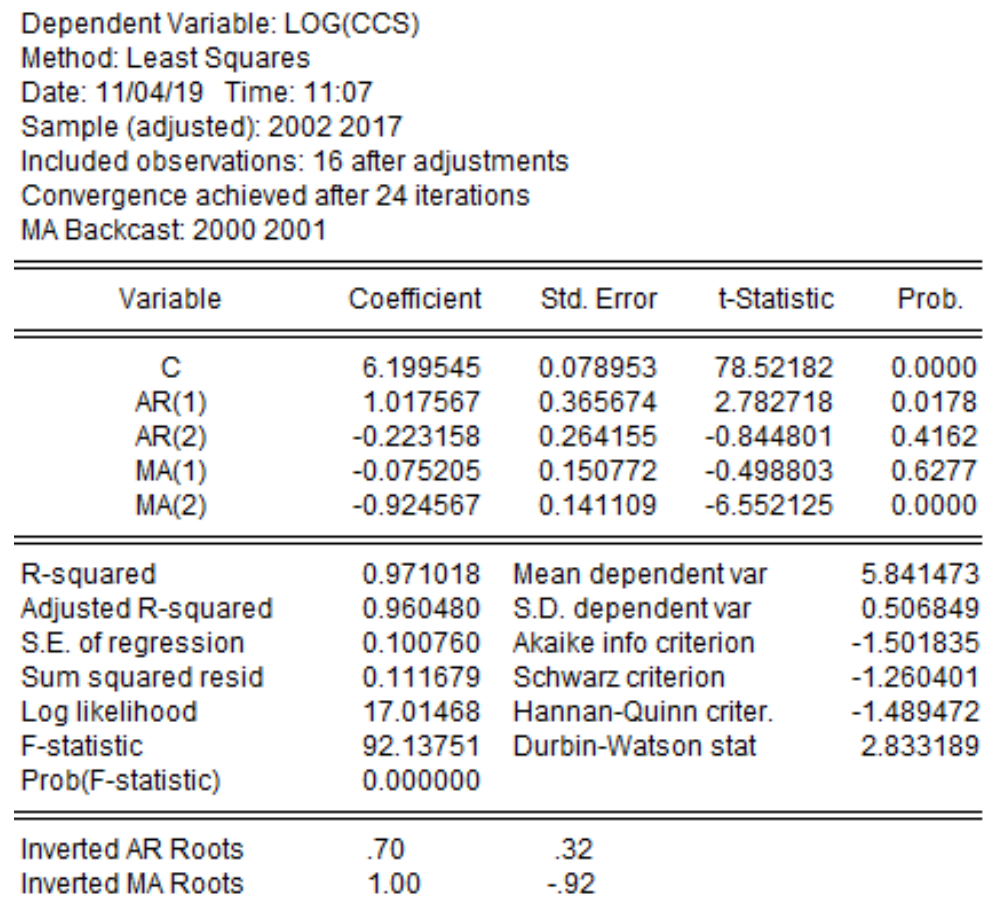

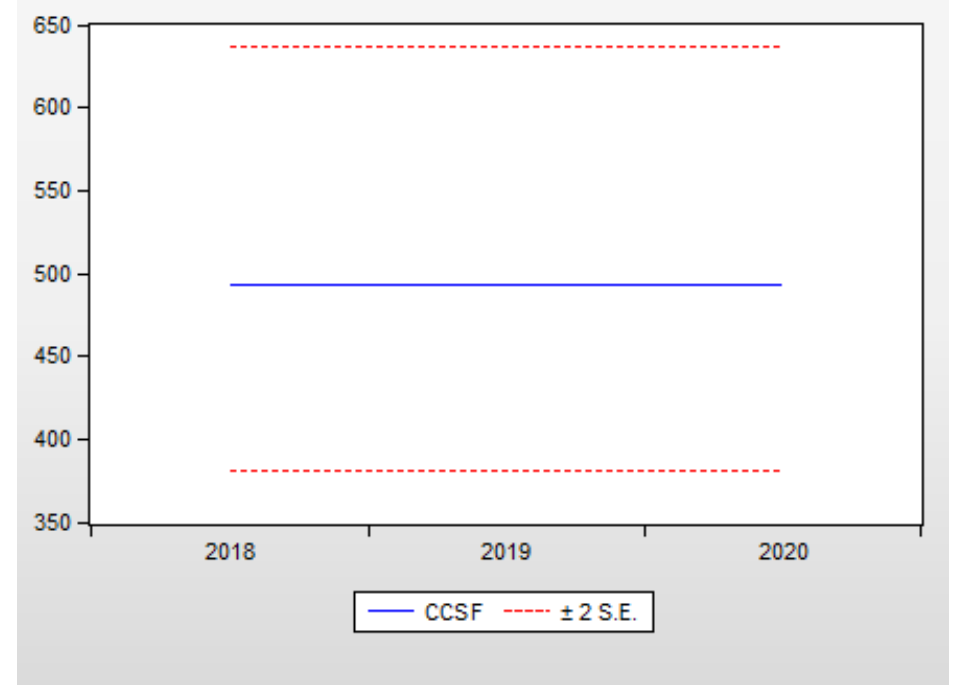

Figure 5. Forecast CCS from 2018 to 2020 


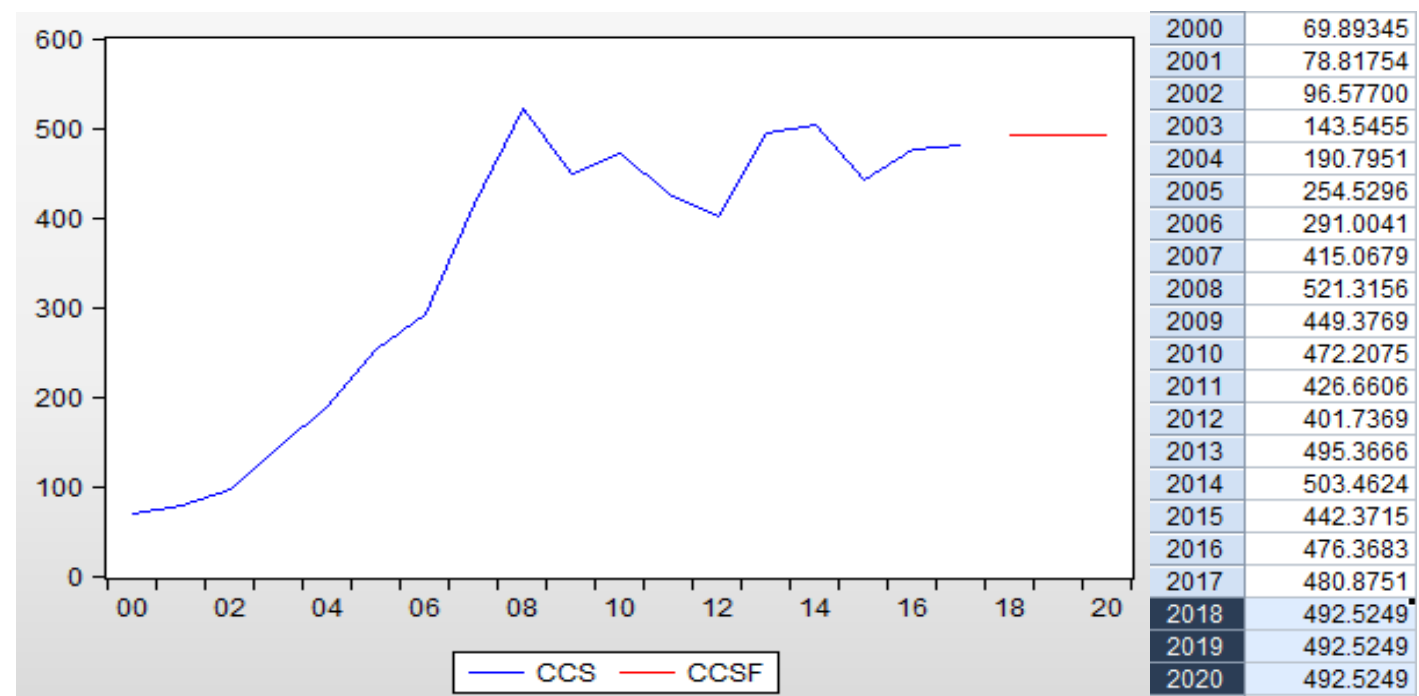

Figure 6. Out-of- sample static forecast plot of CCS

As a matter of fact, the weather we did in this paper shows that current expenditure on health per capita will increase by an average of 11.64 euros per capita.

\section{Conclusions}

As a result of multifactorial modeling we find that increasing the share of direct payments in total health spending increases the total expenditure higher than the share of public expenditure on health care in total health expenditures. Thus, increasing direct payments affect a greater change of current health expenditure per capita in Romania, compared with public health expenditure.

In these circumstances it is necessary to develop the implementation of health funds in personal accounts of accumulation and medical insurance optional as ways of funding the system of health care in order to diversify the structure of funding sources by reducing direct payments in total health expenditures.

\section{References}

1. Adler, N., E. (1994). "Socioeconomic status and health: The challenge of the gradient”. American

2. Becker, G., S. (1994). Comportamentul uman - o abordare economică, Editura All, București

3. Bellavance, F., Dionne, G., Lebeau, M. (2009). „The value of a statistical life: a meta-analysis with a mixed effects regression model”. Journal of Health Economics; 28(2):444-464. doi: 10.1016/j.jhealeco.2008.10.013.

4. Benartzi, S., Beshears, J., Milkman, K., L., Sunstein, C., R., Thaler, R., H., 18 Shankar, M., Tucker-Ray, W., Congdon, W., J., Galing, S. (2017).

„Should Governments Invest More in Nudging?”, Psychological Science. June-05-2017. doi: 10.1177/0956797617702501

5. Ciupagea C., Manoleli, D., Niţă, V., Papatulică, M., Stănculescu, M. (2006). „Direcții strategice ale dezvoltării durabile”. Studiu al Institutului European din Romania. Disponibil lahttp://www.ier.ro/webfm_send/5080

6. Dunn, W., N. (2010). Analiza politicilor publice, Polirom, Iași.

7. Ghețău, V. (2016). „Analiza Sănătatea românilor”, 26 mai 26, Contributors.ro, disponibil online la http://www.contributors.ro/administratie/asigurari-sociale/analizasanatatea-romanilor/.

8. Kotler Ph., Clarke R.N. - Marketing for Health care Organizations Prentice Hall, New Jersey,1987.

9. Managementul Serviciilor de Sănătate - Abordare Prin Proiecte, Autori Florentina Ligia Dana Galieta Furtunescu Mincă, Editura Universitară „Carol Davila” București, 2010 